\title{
DIGITALCOMMONS
}

@WAYNESTATE -

Wayne State University

Social Work Faculty Publications

Social Work

$11-25-2014$

\section{Ending poverty in Mongolia: From socialism to social development}

Richard J. Smith

Wayne State University, smithrichardj@wayne.edu

\section{Recommended Citation}

Smith, R. J. (2014). Ending poverty in Mongolia: From socialism to social development. International Journal of Social Welfare, Advance Online Publication. doi:10.1111/ijsw.12113

Available at: http://digitalcommons.wayne.edu/soc_work_pubs/42

This Article is brought to you for free and open access by the Social Work at DigitalCommons@WayneState. It has been accepted for inclusion in Social Work Faculty Publications by an authorized administrator of DigitalCommons@WayneState. 
NOTICE IN COMPLIANCE WITH PUBLISHER POLICY: This is the peer reviewed version of: Smith, R. J. (2014). Ending poverty in Mongolia: From socialism to social development. International Journal of Social Welfare, Advance Online Publication. doi:10.1111/ijsw.12113, which has been published in final form at http://dx.doi.org/10.1111/ijsw.12113. This article may be used for non-commercial purposes in accordance with Wiley Terms and Conditions for self-archiving. This version may have been formatted for archiving; see supplemental material at http://digitalcommons.wayne.edu/soc_work_pubs/42 for unformatted final accepted manuscript copy. 


\title{
Ending poverty in Mongolia: From socialism to social development
}

\author{
Richard J. Smith, MFA, MSW, PhD1
}

\begin{abstract}
While recent literature on social welfare has included Asian countries, less is known about low-income and former socialist countries in Central Asia. This article combines a documentary-historical method with a valuecritical approach to analyze Mongolia's social policy response to poverty. Mongolia is unique in Asia because it transformed from nomadic pastoralism to socialism without a phase of capitalist industrial development. The case study found that Mongolia lost social welfare when it transitioned from socialism, a statist model, to market liberalism and multiparty democracy. In the 21st century, Mongolia has been aspiring to promote social development by redirecting mining revenues to a human development fund. Mongolia is potentially an exemplar of social development strategies affirmed at the United Nations Conference for Sustainable Development (Rio+20) regarding a green economy for inclusive growth and poverty elimination. Future social welfare research should consider the importance of sustainability.
\end{abstract}

\section{KEY PRACTITIONER MESSAGE}

- Global standards for tracking poverty alleviation will be integrated with sustainability measures beginning in 2015.

- Mongolia hopes to foster social development and sustainable livelihoods by reinvesting revenues from mining into human capital and health care.

- To sustain future generations, social policy needs to consider the relationship between natural capital, social capital, and financial capital.

\section{KEYWORDS}

poverty, green economy, social policy, social development, Mongolia, sustainable livelihoods

\section{Introduction}

The social welfare literature offers explanatory theories as to why poverty exists and why the nation-state develops interventions to alleviate it. The welfare state literature has been moving beyond a classic discussion of the welfare state as a function of the industrialism (Wilensky \& Lebeaux, 1958) or social movements (Esping-Andersen, 1990, Chapter 1). Countries with different economic bases, colonial histories, and cultures do not fit these models, such as the "little tigers" in East Asia (Midgley, 1986), or Palestine in West Asia (Safadi \& Easton, 2014). The social welfare literature has paid less attention to former socialist nation-states in Central Asia, such as Mongolia, a country whose economy depends on mining and pastoral nomadism. Research on this region is critical because the United Nations (2012) will migrate from its former Millennium Development Goals (MDGs) to new Sustainable Development Goals (SDGs) in 2015. This will finalize the integration of social development, economic development, and environmental protection first envisioned by the Brundtland Commission (1987). Explanatory theories of the welfare state have been incorporating the sustainability turn represented by the upcoming SDGs.

The primary contribution of this article is to illustrate, via a case study, how Mongolia aspires to be a model for the new sustainable development regime. To develop this argument, I show how the understanding and causes of poverty in Mongolia have shifted over time. Next, I describe how well social policy has responded during these phases of history. Finally, I ask whether Mongolia's welfare state fits into existing welfare state typologies, or if it could represent an emerging social development welfare state.

\section{Understanding poverty and the social policy response}

Poverty is often measured in one of two ways: absolute poverty or relative poverty (Author, 2007). Absolute poverty is based on the cost of a "breadbasket" of minimum goods necessary for survival. In contrast, relative poverty, or inequality, is a measure of the size of

\footnotetext{
1 School of Social Work, Wayne State University, 4756 Cass Ave, Detroit, MI 48202; Email: smithrichardj@wayne.edu; TEL: $3135772262 ;$ FAX: 3135778770 Final Accepted Manuscript copy dated June 16, 2014
} 
the population at the bottom of a distribution. For example, in the European Union (EU), those who fall below $60 \%$ of the median income are determined to be in poverty (Townsend, 1974). Theories about the causes of poverty include consideration of the natural environment, industry mix, characteristics of the poor, social norms as well as structural explanations regarding political institutions (Blank, 2005; Author, 2007).

Hall and Midgley (2004) presented a useful framework for understanding the main ideological threads of social policy responses to poverty, including statist, enterprise, populist, and holistic approaches. Statist theories of poverty include both a Keynesian emphasis on government expenditure and Marxist approaches to planning and social rights. By the mid20th century, some scholars assumed a linear progression towards economic development that required international trade, foreign investment and technological advancement (Myrdal, 1974; Rostow, 1959). The Marxian tradition includes dependency theory (Cardoso, 1972) and world systems theory (Wallerstein, 1974). These traditions criticize capitalism and argue that poverty is a result of the maldistribution of goods in a global system, with core countries benefiting from cheap labor and raw materials in peripheral countries. Social policy on the left emphasizes regulation, labor protection, redistribution, and import substitution.

The second approach to social policy, the enterprise or market-oriented approach, assumes that poverty is rooted in poorly constructed statist policies or is the result of choices made by the poor. For example, De Soto (2003, Chapter 1) argued that disorganized government bureaucracies without basic institutions to manage and protect private property rob the poor of their ability to capitalize on their land and prevent them from forming businesses to grow wealth.

Third, the populist ideology places the cause of poverty in social forces and cultural norms at the community level. For example, "negative social capital" may create leveling pressures that keep people in poverty or create conditions favorable to corruption (Blank, 2005; Woolcock, 1998). Finally, Hall and Midgley (2004) suggested that it may be possible to combine elements of the three ideologies to form a holistic, or pluralist approach to social policy, which is the primary instrument of the welfare state. I argue that it is from this holistic social development approach that the sustainability turn in social welfare emerges.

\section{The evolution of the East Asian welfare state}

Global sustainability has become an international priority, so it is plausible that welfare states adapt social policy in the context of this environment. Explanatory theories of the welfare state have evolved from attempting to describe an ideal process that applies to all nation-states, to recent attention on how particular circumstances shape policy innovation. The early structural functionalist model argued that the welfare state is a function of a differentiated industrial society with surplus wealth (Wilensky \& Lebeaux, 1958). Some welfare states offer policies that are institutional, provided to all as a normal function of society (e.g., public education and retirement pensions). Others offer policies that are residual, provided only on a temporary, emergency basis (e.g., unemployment and family assistance). Welfare state theories evolved to understand the role of social movements, particularly organized labor, in mobilizing voters to elect a political party favorable to welfare policies (Esping-Andersen, 1992). This welfare state typology divided industrialized welfare states into three categories: a) state-oriented social democracies (e.g., Scandinavian countries), b) family-oriented conservative welfare states (e.g., France and Germany), and c) market-oriented liberal welfare states (United Kingdom and United States) (EspingAndersen, 1990, Chapter 1).

As welfare state scholars examined other countries, these typologies became problematic. Midgley (1986) rejected the application of this typology in Asia, suggesting that social policy development was complex and idiosyncratic. More recently, scholars have classified East Asian welfare states as "productivist" (Holliday, 2000) or, as other scholars call them, "developmentalist" (Lee \& Ku, 2007). East Asian welfare states resemble liberal states in their patchwork of means-tested benefits, but they tend to favor economic policy over social policy. This literature discusses wealthier East Asian countries such as Japan, Singapore, and South Korea, as well as specific regions in China such as Hong Kong, and Taiwan (Aspalter, 2006). For instance, while the family is a primary source of social welfare in Taiwan, many elderly rely on cash transfers from the state $(\mathrm{Li}, 2013)$.

Some welfare state literature are case studies, others develop welfare state typologies using exploratory factor analysis, which describe the full set of sample nation-states but cannot distinguish cause from effect. 
Data generally involve national expenditures on social welfare programs and an analysis of eligibility rules and may assume that more spending implies more welfare. Those that consider the role of tax expenditures, voluntary contributions, and magnitude of need in the analysis of the welfare state, find that liberal states are far from being "least generous" (Gilbert, 2009). Just as a scholarly attention to occupational welfare (Titmuss, 1965) informs the liberal welfare state, an attention to social development and sustainable livelihoods should inform states that rely heavily on natural capital extraction and animal husbandry.

\section{Mongolian context}

Mongolia represents a unique case study for demonstrating how the global shift from MDGs to SDGs is necessary and for illustrating the importance of natural capital and sustainable livelihoods, a factor that is less obvious in wealthier countries. Mongolia is a former socialist republic that moved in the first decade of the 21 st century from being a low-income to lowermiddle-income nation (The World Bank, 2012), and from a least developed county to a medium developed country (United Nations Development Program Mongolia, 2007, 2011). It is landlocked between China and Russia, putting it at a geographic disadvantage in terms of trade. Its natural capital is restricted by an arid climate, with a growing season of less than three months and limited grazing land. Temperatures may drop below -40 degrees Celsius in the winter, and severe blizzards kill livestock in overgrazed areas. Much of the economic development in Mongolia comes from wealth generated from mining copper, gold and other minerals. Mining creates a sustainability paradox for a country rooted in nomadic pastoralism. According to the CIA Factbook (2011), about 34 percent of Mongolians are employed in agriculture, 54 percent in the service sector, and 5 percent in industry, with 7 percent in other occupations. Labor exports and overseas remittances have been growing, with an estimated 15,000 to 20,000 Mongolians living in the United States alone (Bahrampour, 2006). The 2010 gross domestic product per capita was USD \$2,294 (PPP) (United Nations Development Program Mongolia, 2011). Despite these challenges, the Government of Mongolia plans to use mining revenues to establish a Human Development Fund in order to sustain its welfare state (United Nations Development Program Mongolia, 2011). Even though progress has been made in social development, poverty has increased from a low of 29.3 percent in 2007 to 39.2 percent in 2010 , in part caused by a devastating blizzard (United Nations Development Program Mongolia, 2011). Does Mongolia fit the "productivist" or "developmentalist" mode of the welfare state that privileges economic growth? Is it following a social development welfare state that balances economic growth with sustainable livelihoods?

\section{Methods}

This article was a case study using a documentaryhistorical approach to understand contemporary policy events in a historical and cultural context (Aita \& McIlvain, 1999). It drew from a variety of data sources using an analytic framework to provide descriptive and explanatory understandings of a social phenomenon. Data sources included archival literature, poverty data from the National Statistics Office, and reports from national and multilateral agencies. I consulted key Mongolian histories available in English for background information. Keywords used to search library databases, Social Work Abstracts and Social Services Abstracts, included "Mongolia(n) and poverty." The analytical framework was a value-critical approach (Chambers \& Wedel, 2004). Each element of social policy was described using the following categories: a) social problem definition, b) causal analysis, c) ideology and values, d) gainers and losers, e) service delivery, and f) financing. The unit of analysis was the nation-state of Mongolia over time. Thus it did not constitute human subjects research. The purpose was to make a critical extension of existing welfare state typologies. I examined four periods of Mongolian history against the reigning ideology and values of the time: a) pre-modern feudalism; b) statist socialism; c) enterprise shock therapy; and d) a 21st century social development and sustainable livelihoods approach.

\section{Findings from case study: poverty and social policy in Mongolia}

Mongolian poverty rises in periods of isolation and falls during periods of trade and global integration. While the country is rich in mineral resources and human capital, the carrying capacity of the land varies dramatically year to year, depending on the weather, now challenged by desertification and climate change. Historical anthropologists Bruun and Narangoa (2006) 
posited four moments of Mongolian pastoralism: a) a mobile military pastoralism during the days of the Mongolian empire, b) a pastoral monastic era during the Manchu dynasty, characterized by Buddhist influence, c) communist modernization through most of the 20th century, and d) contemporary urbanism-pastoralism, characterized by intractable rural poverty in a relatively stable international order. These phases inform, but do not exactly correspond to the periods used in this paper. See Table 1 for a summary of the value-critical analysis of these four phases of Mongolian anti-poverty policy history.

\section{Table 1. Summary of value-critical analysis}

\begin{tabular}{ll} 
Pre-modern & \\
\hline Poverty definition & NA \\
Causal analysis & Poor character, bad luck \\
Ideology and values & Populist and traditionalist \\
Gainers & Monks and nobility \\
Losers & Families \\
Service delivery & Temples \\
Financing & Donations, pastorialism, and petty trade \\
\hline
\end{tabular}

\begin{tabular}{ll} 
Modern & \\
\hline Poverty definition & Absolute \\
Causal analysis & Oppression \\
Ideology and values & Statist and Marxist \\
Gainers & Herders and workers \\
Losers & Monks and nobility \\
Service delivery & Collectives and state \\
Financing & The Soviet Union and COMECON \\
\hline
\end{tabular}

\begin{tabular}{ll} 
1990s & \\
\hline Poverty definition & Absolute and participatory \\
Causal analysis & Statism and protectionism \\
Ideology and values & Enterprise and market \\
Gainers & Entrepreneurs and investors \\
Losers & Women and children \\
Service delivery & Market, state, and ad hoc projects \\
& $\begin{array}{l}\text { Development assistance, privatization of assets, value } \\
\text { added tax }\end{array}$ \\
\hline
\end{tabular}

\begin{tabular}{ll} 
21st century & \\
\hline Poverty definition & Participatory, inequality adjusted \\
Causal analysis & Human, social, and natural captial deficits \\
Ideology and values & Pluralist and sustainable \\
Gainers & Mongolian citizens (TBD) \\
Losers & Foreign investors \\
Service delivery & Market, state, one stop shops, community \\
Financing & Development assistance, tax on mining revenues \\
\hline
\end{tabular}

\section{Phase \#1: Feudalism in Pre-modern Mongolia (1260-1920)}

In pre-modern times, Mongolia had a feudal political economy based on pastoral nomadism and trade. Given the rocky soil and arid climate, poverty then in Mongolia was a function of natural endowments and luck. Nomadic pastoralism allowed Mongolians to have a livelihood free from China and Russia. Before Chingiss Khan, Central Asia was a vast area of tribes and microcultures that shared a nomadic lifestyle and lived in felt tents (Morgan, 1986). The religion was Shamanistic, although Islam rapidly spread (Heissig \& Samuel, 1980). The Mongolian Empire opened up the Silk Road to Europe after centuries of isolation, placing it in the global center. It created trade networks and a rule of law that allowed new ideas and new markets to form. However, as the empire declined, Mongolian standards of living also declined. In the 17th century, after Mongolia moved from the core to periphery, Mongolia had to pledge allegiance to the Manchu dynasty in China for military protection. Trade policy from 1691 to 1911 deliberately isolated Mongolia and restricted trade to short-term licensing agreements (Bawden, 1991). Consequently, Mongolia became a buffer between Russia and China in this period, as did the military outposts on the Russian border (Bawden, 1991, p. 15). When trade to the outside was cut off, poverty and disease rose in Mongolia. The primary site of the market, health care, education, and social service delivery was the Buddhist temple, financed by donations and enterprise.

By 1911, the Manchu dynasty had fallen, but poverty persisted. Observers noted a population of day laborers that lived in gers, Mongolian felt tents, outside formal settlements (Bawden, 1968; Sneath, 2006). Since urban areas attracted traders, Mongolians associated urbanity with foreigners and dishonest dealings (Sneath, 2006). Mongolia's reputation in early 20th century travel literature involved poverty and prostitution (Benwell, 2006). Mongolian identity at that time developed a split between urban and rural. For Mongolians, closeness to nature, sincerity, tradition and hospitality defined rural life, while the competing urban elite-centrist impulse expressed a cosmopolitan culture that saw the rural population as poor and backward (Sneath, 2006). In short, pastoral nomadism defined Mongolian identity and involvement with foreigners was subject to 
criticism that it was destroying the Mongolian way of life.

\section{Phase \#2: The socialist era: ending poverty through revolution (1921-1990)}

Mongolia leapfrogged directly from pastoral nomadism to socialism without an intervening period of capitalism (Butler, 1991). In the socialist period, poverty was understood to be caused by feudalism and oppression by the Chinese. State socialism responded to poverty by building a welfare state along an institutional model. When Mongolia declared independence from China in 1921, it had trouble getting recognition from the international community, Russia being a notable exception (Bawden, 1968). Soviet troops marched into Urga to support the revolution and help build the world's second Socialist Republic. Next, the Mongolian People's Revolutionary Party (MPRP) engaged in general democratic transformation from the revolution in 1921 through 1940 (Prasad, 1995), but Mongolia's economic base remained pastoral. However, one third of the adult male population was in the monastery. Until 1929, Mongolia had a constitutional monarchy, with the MPRP as the sole party in parliament (Bawden, 1968). At the time, the MPRP was a diverse party that included representatives from royalty and the temple.

Mongolia's progress towards socialism was slow as the new government collectivized animal husbandry under the leadership of Choibalsan. Various regions, the west in particular, and temple militias waged a lowintensity conflict against the MPRP and its army (Bawden, 1968). It is difficult to know for certain what happened during the early days of socialism because the state controlled almost all published material. This makes it difficult to find independently verified data (Bawden, 1968; Sanders, 1987). After World War II, Mongolia became a model socialist welfare state. From 1940 to 1960, Mongolia built the "foundations of socialism," which included heavy industry and popular education (Prasad, 1995). The golden years of socialism ran from 1960 to 1990 and involved diversification of industry. The Soviet Union invested heavily in mineral extraction (Campi, 2006). The last phase of the socialist era began in the 1980s under glasnost, when the MPRP introduced market reforms (Bawden, 1991; Sanders, 1987).

Under the MPRP, the first Mongolian Trade Unions organized in the 1920's were responsible for monitoring social welfare provision in all aspects, including pensions, education, day care, housing, and health care (Sanders, 1987). Trade unions also had special access to sanatoriums, a curious hybrid of a vacation resort and residential health treatment facility (Sanders, 1987, pp. 76-77). Each soum center had a post office, clinic, school, cultural center, police and housing for civil servants (Sneath, 2006, p. 148). The MPRP's modernization program civilized rural settlements and, in turn, institutionalized nature as a place to go to escape urbanization and relaxed. In this modernization process, the state replaced nature as the primary source of livelihood.

Table 2. 1972 wages and pensions under socialism

\begin{tabular}{|c|c|c|}
\hline & 1972 Maximum & 1972 Minimum \\
\hline Type of work & $\begin{array}{l}\text { Doctors, } \\
\text { inspectors, and } \\
\text { skilled factory } \\
\text { workers }\end{array}$ & Clerical work \\
\hline Mongolian tugriks $\mp(\mathrm{MNT})$ & $\mp 700$ MNT & $\mp 450 \mathrm{MNT}$ \\
\hline US dollars \$ & $\begin{array}{l}\$ 210 \text { ( } \$ 1,024.59 \\
\text { in } 2005 \text { dollars) }\end{array}$ & $\begin{array}{l}\$ 135 \text { (\$658.66 in } \\
2005 \text { dollars) }\end{array}$ \\
\hline Mongolian tugriks $\mp(\mathrm{MNT})$ & $\begin{array}{l}50 \% \text { of wages } \\
\text { for those with } \\
\text { wages }<\mp 600 \\
\text { MNT } \\
40 \% \text { of wages } \\
\text { for those with } \\
\text { wages }>\mp 600 \\
\text { MNT }\end{array}$ & ₹150 MNT \\
\hline US dollars \$ & $\begin{array}{l}\$ 180 \text { ( } \$ 878.22 \\
\text { in } 2005 \text { dollars) }\end{array}$ & $\begin{array}{l}\$ 45 \text { (\$219.55 in } \\
2005 \text { dollars) }\end{array}$ \\
\hline
\end{tabular}

Note: Table 2 was adapted from Sanders (1987). Dollar equivalents in 2005 are based on the value of the consumer bundle, or buying power of the monthly salary in today's dollars (Officer \& Williamson, 2011). This is indexed using the US consumer price index, not the Mongolian index. Thus, it overestimates housing, health care, meat, milk, and education (i.e., domestic supply), but underestimates energy and consumer goods (imports).

By the 1970s, Mongolian law had established social rights, beginning with pensions for urban workers (Butler, 1991). Retirement age was set at 60 for men and 55 for women and those with incomes greater than $500 \mathrm{MNT} /$ monthly paid 5 percent income tax (Sanders, 1987, p. 121). See Table 2 for pension benefit levels from 1972 (Sanders, 1987). These pensions expanded to agricultural associations and the disabled in 1984. Rural collective farms provided disability and survivor benefits (Sanders, 1987, p. 120). In 1980, the government established labor protections. Women received paid maternity leave for 101 days and received 
first class "Mother Hero" medals for having eight children and second place medals for five children (Sanders, 1987, pp. 82-82). Mothers also received a per child cash grant for up to nine children (Sanders, 1987, pp. 118-119). By the 1980s, Mongolians enjoyed guaranteed employment, pensions, universal education, universal health care, and subsidized day care. In fact, unemployment was low because it was potentially illegal (Sanders, 1987, p. 123).

Perestroika came to Mongolia in the 1980s. After a series of market reforms, the United States began diplomatic relations with Mongolia in 1987 (Rossabi, 2005). In 1988, Mongolia had the highest GNP among socialist states in Asia, but it was the least wealthy of the COMECON member nations (Kaser, 1991, p. 95). Furthermore, Kaser (1991) noted that Mongolia had low rates of personal savings, because, with state pensions, there was no reason to save. In an exercise of "petropolitics" (Friedman, 2006), the Soviet Union had been providing the most investment, using profits from its oil and natural gas sales. After the Soviet Union dissolved, Mongolia lost its primary source of international investment and was left with debt owed to Russia (Rossabi, 2005, pp. 6-10). This pushed Mongolia back into the periphery because its primary relationships had been through the Soviet Union and COMECON.

\section{Phase \#3: The era of multiparty democracy: ending poverty with neo-liberal shock therapy? (1991-1999)}

Single party rule ended abruptly. After a series of public demonstrations led by future Democrats Zorig, Khulan, Ganbold, and others, the MPRP renounced MarxismLeninism in 1991, and agreed to multi-party democracy (Rossabi, 2005). The MPRP drafted the new constitution in partnership with the various Democratic parties, traditionalists, and Greens. The collapse of the Soviet Union resulted in the abrupt end to military and financial aid. During the 1990s, Mongolia received bilateral aid primarily from Japan, Germany, and the United States (Jones \& Kumssa, 1997). This aid went to fund democratization, agriculture, infrastructure, and poverty alleviation. An early reform involved the mass privatization of state owned enterprises, including the collective herds. Citizens, who knew nothing about capitalism, were given equal shares of their collective in the name of social equity, but many simply cashed out early and were not able to realize any asset-building potential. Because many of the enterprises were not profitable, they closed, leaving rural areas without jobs and basic social services (Jones \& Kumssa, 1997).

After the collectives were privatized, many former members moved to cities to escape rural poverty. Likewise, many "new herders" were those who lost jobs when state-owned industries closed. They moved to the country, but did not necessarily know how to raise livestock (Benwell, 2006, p. 112). Since rural wealth was measured in livestock, and new herders did not have strict state-imposed controls on sizes, families were encouraged to overgraze. The day-to-day realities of the transition were stark (Kaplonski, 2004). Bread and other goods were rationed. Although income more than doubled, it did not compensate for inflated prices of goods and services. Stores sold Swedish furniture, Japanese electronics, and Korean food, but not everyone could afford shopping in these "de facto museums of capitalism” (Kaplonski, 2004, pp. 44-47). In 1994, the World Bank and UNDP funded the first transitional Poverty Alleviation Program to assist the estimated 26.8 percent of the population in poverty (Rossabi, 2005, p. 135). The program budgeted $\$ 2.5$ million for infrastructure and public works, $\$ 2$ million for health, $\$ 2$ million for education, and $\$ 3.2$ million in microcredit for vegetable growing. Meanwhile, the minority Democratic Union promoted a model of poverty alleviation to support public works and small business development consistent with a free market philosophy whose adherents believed cash and in-kind donations created welfare dependency.

In 1995, the International Republican Institute, a US funded NGO, persuaded center-left and right parties to form a coalition and run an effective campaign using the slogan "Contract With Mongolia." Consequently, in the 1996 election, the MPRP's 70-year rule ended with the election of National Democrat Enkhsaikhan as Prime Minister. Jones and Kumssa (1997) expressed hope that this political change would facilitate decentralization and allow small and medium sized firms to thrive in harmony with the environment. After consultation with Bretton Woods institutions and economist Jeffrey Sachs, Prime Minister Enkhsaikhan introduced a "shock therapy" economic plan that involved cutting public services, eliminating tariffs, introducing a national sales tax, and introducing other currency stabilization measures. He also engaged in a "New Zealand" style of governance reform that involved decentralizing authority to cities, aimags, and soums, contracting out services, and privatizing assets 
(Nixson \& Walters, 1999). Although the currency stabilized, the new government had no revenues because few paid taxes. Privatizing state-owned enterprises provided the only source of revenue for the Enkhsaikhan government. One key element to Sachs' (2005) shock therapy, debt cancellation, eluded Mongolia at the time. Mongolia held $\$ 1.36$ billion in external debt - one of the highest in Asia. The government disputed debt that arose from development costs accrued from the seventy years of Soviet assistance (Rossabi, 2005, pp. 6-10). This issue was not resolved until the Canadian Ivanhoe Mines, Ltd. purchased $\$ 50$ million in bonds toward repayment of the debt almost a decade later (Rossabi, 2005, p. 201).

To track progress on poverty alleviation, the World Bank and State Statistical Office conducted a Living Standard Measurement Survey in 1995, an absolute measure with benchmarks developed through a series of nationally representative focus groups. The survey established a baseline national poverty rate of 36.3 percent. Critics noted two key limitations: a) the breadbasket measure in the survey did not include selfprovided resources, such as livestock, and b) it did not correct for age and gender differences in nutritional needs. Critics felt that the true poverty rate may have been closer to 51 percent (Mearns, 2004; Rossabi, 2005, p. 137; Walters, Marshall, \& Nixson, 2012).

In 1998, poverty fell to 35.6 percent, measured using a different method, but that change did little to satisfy critics. Rossabi (2005, p. 138) noted criticisms regarding the government's explanation of inadequate economic growth and argued that tax evasion, privatization, income inequality, and corruption exacerbated poverty. Also, microloans had unfavorable rates and offered little return on investment for those who participated. Furthermore, Walters and Nixson (2006) argued that government had engaged in a privatization scheme with neither proper management controls nor an understanding of how to equitably redistribute dividends to citizens.

In response to declining national income, the IMF, at a donors' meeting, proposed further cuts in government spending to ensure macroeconomic stability and uninterrupted debt service. Rossabi (2005, pp. 148-150) lamented that a whole generation of Mongolians had grown up in a "culture of poverty" and argued that emerging adults needed not only jobs and loans, but social services to help cope in a changed Mongolia. Indeed, such a system had been in development beginning since 1995, but it did not mature until a decade later.

\section{Phase \#4: Social development and sustainable livelihoods in the 21st century (2000-2010)}

Social policy language in Mongolia took a sustainability turn in the new decade. Shock therapy and corruption scandals brought the new Democratic coalition through four governments before losing power to the MPRP in 2000. Because of the poor performance of the first poverty alleviation strategy, Keith Griffin, a senior development economist from University of California, Riverside, in 2001, led a team of UNDP economic consultants to develop a new anti-poverty strategy. They recommended undoing some shock therapy by reintroducing tariffs and imposing a luxury tax on cars. Griffin also advocated encouraging personal savings and supporting cooperative development with meaningful community participation (Rossabi, 2005, pp. 148-150). Overgrazing, a tragedy of the commons, was noted by Griffin (2003) as a crucial barrier to ending rural poverty. Indeed, in feudal times there was an informal system of assigning pastures to prevent overgrazing, a tradition that was lost in collectivization.

International development organizations introduced microfinance programs to replace financial services that had been provided by state banks. By 2005, there were approximately 1,600 microfinance institutions serving over 10,000 persons (Okamoto, 2011). Because this saturation was inadequate to manage risk during natural disasters, the Japan Bank for International Cooperation, World Bank, and government of Mongolia developed a pilot microinsurance program to provide herders with affordable livestock coverage.

As the developmentalists at UNDP tried to humanize the neo-liberal reforms, Campi (2006) criticized UNDP for linking anti-poverty efforts to urbanism or, as she puts it, sedentarization. She argued that Mongolia built key cities for political, military or industrial reasons, but they were not sustainable without foreign subsidy. Only policies that incorporated Mongolia's nomadic traditions would be sustainable. Other scholars integrated gender with the rural perspective. For example, "free time," for rural women, meant making clothes, drying meat, curdling milk and other chores (Benwell, 2006, p. 113). Indeed, rural women spent 20.7 percent of their time on household maintenance, while urban women spent 15.0 percent. Rural men spent 31.5 percent of their time working, 
while urban men spent only 19.3 percent of their time working (National Statistics Office, 2009). Traditionally, poverty was associated with laziness in current or previous lives, but time-use data showed that the typical rural Mongolian worked hard, was willing to relocate, as well as willing to change careers to avoid poverty. Benwell (2006) argued that women in particular were vulnerable to occupational stratification and domestic violence.

The School of Social Work at the Mongolian State University of Education (MSUE) developed curricula to address contemporary social problems (Hayashi, Frost, Yamashita, Khuajin, \& Nyamsuren, 2009). Under socialism, there was no profession of social work because health care, education, and social insurance were universally provided as a matter of right. The rise of family violence, alcohol abuse, and child homelessness led the Government of Mongolia to partner with international agencies such as UNICEF, Save the Children UK, and World Vision, to develop social welfare and child protection laws, and begin training for professional social workers to implement this legislation (Namdaldagva, Myagmarjav, \& Burnette, 2010). MSUE became the first institution to offer degrees in social work and training in child welfare, school social work, and social development. Namdaldagva et al. (2010) noted that Mongolian social workers created a social development curriculum with input from the Czech Republic, Denmark, Germany, India, Japan, Russia, and the United States, rather than uncritically adopting a single Western social work model.

Dissatisfaction with the MPRP on poverty and governance issues resulted in a state of emergency after the 2008 parliamentary elections. Democratic Party candidate Elbegdorj was elected President 51 to 47 percent over Enkhbayar in the following year's presidential election (Central Intelligence Agency, 2013). In 2010, the MPRP dropped "Revolutionary" from its name (MPP), and embraced a "third way" ideology (Giddens, 2000). The new MPP Prime Minister Batbold worked with the democratic coalition to find the best method for redistributing mining revenues. President Elbegdorj invited entrepreneurship scholar De Soto to consult on the structure of the Human Development Fund to avoid problems that occur when export-oriented countries spend revenues immediately and in turn cause rising inflation and inequality (Forsythe, 2010).
Mongolia hopes to avoid increasing inflation by saving revenues for periods when prices fall and investing primarily in productive human capital and physical infrastructure that will have long-term returns. As such, it has developed a hybrid between Singapore's Provident Fund, an asset-based pension system, and the Alaska Permanent Fund, a citizen dividend program (Hook, 2011). In the Singapore case, contributions are mandatory and universal, but benefits are restricted to the value of prepaid contributions. Furthermore, Singapore encourages asset building by requiring that the Provident Fund used to make a down payment on an apartment built by the state. The Government of Singapore in turn invests the fund abroad to increase national income (Holliday, 2000; Midgley, 1986, 1999). The Alaska Permanent Fund, in contrast, pays out dividends, requires no contribution from citizens, and allows the state to reinvest revenues. Singapore's model is categorized as a productivist welfare state, while Alaska's is more of a redistributive institutional model.

Mongolia will combine the two approaches by having cash dividends, issuing stock in the fund, and offering in-kind transfers for education, health insurance, and housing. Cash transfers from the Human Development Fund are expected to be $\$ 92-\$ 200$ per year. This will be approximately equal to one month's pay. Each citizen, including those overseas, will receive 536 shares that may not be sold until maturity. They may be willed to children and grandchildren but not otherwise transferred (United Nations Development Program Mongolia, 2011). This prohibition on early sale is a response to lessons learned from privatization in the 1990s, when poor families sold shares for cash at a discount upon receipt before the shares had a chance to grow (Jones \& Kumssa, 1997). The fund will subsidize all health insurance and pensions and pay for the second semester per year for all students (Hook, 2011; United Nations Development Program Mongolia, 2011). This new proposal, if implemented as planned, will direct growth in the aging infrastructure where needed and also provide an asset-based safety net for the poor in housing, health care, and education. This act resolves issues raised in Griffin (2003) regarding the need for revenues for social development. This is a unique form of welfare pluralism that finds common ground between social democratic and libertarian policy, a type of holistic social policy envisioned by Hall and Midgley (2004). If implemented, it could represent an exemplar social development welfare state. 
Because Mongolia's pastoral nomadic heritage is based on natural capital and is already close to carrying capacity, the combination of infrastructure investments and human development investments could further degrade the rural landscape. President Elbegdorj has committed to manage natural capital, by revoking mining permits in sensitive watersheds, introducing a pollution payment principle, and ensuring that the economy is centered around poverty elimination (Khuldorj, 2012). His administration will train herders to grow sea-buckthorn fruit, a marketable traditional medicine that prevents desertification. Urban policy will be reducing air pollution through energy efficient stoves, and upgrading informal settlements to reduce the need for commuting to the city center. Mongolia is working with Japan to shift from coal to wind and solar energy as part of the Asian Super-Grid. Indeed, in 2012 President Elbegdorg won the United Nations
Environmental Program (2012) "Champion of the Earth" award for work towards sustainability.

While Mongolia is positioning itself to meet the new SDGs, it has yet to make progress towards poverty reduction for its MDGs. See Table 3 for Mongolia's progress towards the MDGs (National Development and Innovation Committee, 2009; United Nations Development Program Mongolia, 2007; 2011; World Bank, 2011). While Mongolia has experienced exceptionally high GDP growth, all measures of poverty are rising and are almost double the 2015 target. Unfortunately, implementation of the human development accounts has stalled because the issue of mining revenues became an election issue in 2013 (Kohn, 2013). However Elbegdorj won again over wrestling champion Bat-Erdene narrowly 51 to 43 percent (Ganbat, 2013), which should allow the mining project to move forward.

Table 3. Progress toward Millennium Development Goals for Mongolia

\begin{tabular}{|c|c|c|c|c|c|c|c|c|c|c|c|c|}
\hline Measure & 1990 & 1995 & 1998 & 2000 & 2002 & 2005 & 2006 & 2007 & 2008 & 2010 & $\begin{array}{r}\text { MDG } \\
2015 \\
\end{array}$ & Source \\
\hline $\begin{array}{l}\text { Poverty headcount ratio }(\%) \\
\text { Poverty gap ratio at national poverty }\end{array}$ & $\ldots$ & 36.3 & 35.6 & $\ldots$ & $\ldots$ & $\ldots$ & 32.20 & 29.3 & 35.2 & 39.2 & 18 & NDIC \\
\hline line $(\%)$ & $\cdots$ & 10.9 & $\cdots$ & $\cdots$ & 11.0 & $\cdots$ & 10.10 & 8.8 & 10.1 & $\cdots$ & 6 & NDIC \\
\hline $\begin{array}{l}\text { Share of the poorest quintile in } \\
\text { national consumption }\end{array}$ & $\ldots$ & $\ldots$ & $\ldots$ & $\ldots$ & 7.5 & $\ldots$ & 6.30 & 6.4 & 7.2 & $\ldots$ & 11 & NDIC \\
\hline $\begin{array}{l}\text { Per capita GDP (at current prices, } \\
\text { thousand MNT) }\end{array}$ & 5.10 & $\cdots$ & $\cdots$ & 426 & $\cdots$ & $\cdots$ & 6.30 & 1758.0 & 2305.0 & 2992.0 & 6,800 & NDIC \\
\hline $\begin{array}{l}\text { Per capita GDP in USD }(\$ 1= \\
1,304.348 \mathrm{MNT}) \text { authors' currency } \\
\text { conversion }\end{array}$ & 3.91 & $\ldots$ & $\ldots$ & 326 & $\ldots$ & $\ldots$ & 4.83 & 1348.0 & 1767.0 & 2294.0 & 5,213 & $\begin{array}{r}\text { NDIC } \\
\text { MHDR/ }\end{array}$ \\
\hline $\begin{array}{l}\text { Population below US } \$ 1.25 / \text { day } \\
\text { poverty } \%\end{array}$ & $\cdots$ & 18.8 & 34.2 & $\cdots$ & 15.5 & $\cdots$ & $\cdots$ & $\cdots$ & $\cdots$ & $\cdots$ & $\cdots$ & $\begin{array}{r}\text { World } \\
\text { Bank } \\
\text { MHDR/ }\end{array}$ \\
\hline $\begin{array}{l}\text { Poverty gap at US } \$ 2 / \text { day (PPP) } \% \\
\text { (HDR has wrong label) }\end{array}$ & $\ldots$ & 14.4 & 26.3 & $\ldots$ & 12.3 & 17.3 & $\cdots$ & $\ldots$ & $\ldots$ & $\ldots$ & $\ldots$ & $\begin{array}{r}\text { World } \\
\text { Bank }\end{array}$ \\
\hline $\begin{array}{l}\text { Poverty headcount ratio at } \$ 2 / \text { day } \\
(\mathrm{PPP})(\% \text { of population) }\end{array}$ & $\ldots$ & 43.5 & 68.3 & $\ldots$ & 38.9 & 49.1 & $\ldots$ & $\ldots$ & $\ldots$ & $\ldots$ & $\ldots$ & $\begin{array}{r}\text { World } \\
\text { Bank } \\
\end{array}$ \\
\hline
\end{tabular}

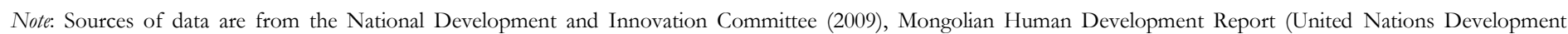

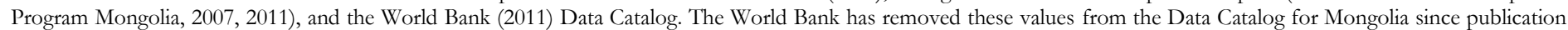
in the Mongolian Human Development Report (United Nations Development Program Mongolia, 2011).

\section{Discussion and Conclusion}

Mongolia's holistic, pluralist approach to social policy represents a sustainability turn because it attempts to harness the green economy for poverty eradication. However, such a social development welfare state is still aspirational. To date, Mongolia has not eradicated poverty. This sustainable approach is akin to the productivist or developmentalist welfare states in Asia (Holliday, 2000; Lee \& $\mathrm{Ku}, 2007$ ), but differs in that Mongolia places more emphasis on the social and environmental because of heavy reliance on natural capital without direct access to seaports for trade. A central challenge for development is a set of conflicting identities: the pastoral nomad in contrast to the global 
trader and messenger. While a feudalistic, traditionalist society based on animal husbandry and a temple economy may have historic and cultural value, it is hardly compatible with ending poverty. While Prasad (1995) praises Mongolia as exceptional for going from core to periphery to modernization, this begs the question of whether having a sustainable livelihood from animal husbandry is normatively "backward." The tension between modernization and urbanization in a nomadic country has challenged both Mongolian policy makers and foreign advisors who implicitly endorse a stage model of economic development (Rostow, 1959). Socialism ended poverty with global capital from Soviet petrodollars but was not sustainable in the long run. Benwell (2006) and Campi (2006) might argue that both socialism and capitalism are at odds with the pastoral identity that values the earth as a mother and the source of a sustainable livelihood. Even Mongolian social workers such as Namdaldagva et al. (2010) attribute social problems to the incursion of sedentary "Western" lifestyles that reject Mongolia's traditional heritage.

An injection of capital for mining will not be sufficient to sustain social welfare in Mongolia. President Elbegdorj appears to understand the limits of mineral extraction. At some point in this century, Mongolia will exhaust all mineral reserves. It is imperative that the financial capital from the mines is well managed, as well as other forms of natural capital. The Human Development Account could test effective ways of trading natural capital for human and social capital. If not, Mongolia will return to the periphery and have to subsist on any remaining grasslands.

\section{Implications for social welfare}

The literature has noted a shift in the welfare state from managing means-tested and universal benefit programs to promoting social development that will allow clients to have long-term, sustainable livelihoods. The Millennium Development Goals captured a social development approach that focused on poverty alleviation. The Sustainable Development Goals complete this conceptual shift by emphasizing the importance of the environment and natural capital in poverty alleviation. The international consensus leading up to the World Summit for Social Development recognized that poverty alleviation required coordination of the social and economic sectors. The social development resolution affected the training of social workers, so they can facilitate economic as well as other social outcomes of their clients. In the post-2015 global agenda, social policy will be harmonized with environmental policy. Likewise, social welfare and the training of social workers will need to be harmonized with environmental protection and training of environmental workers. This need not be daunting. Social workers are already trained to do assessments of individuals, families, and communities. They can work with professional colleagues to assess environmental conditions of clients and learn the impacts these have on health and well-being. Social workers are already trained in policy practice and advocacy for client populations. Social justice requires environmental justice. Social workers can continue to engage policy and begin to advocate in partnership with those who work on environmental issues.

\section{Limitations}

This historical study, by design, has a limited scope and is not intended to be generalizable. The assessment of anti-poverty programs in Mongolia is made more difficult by a lack of accurate, annual poverty data. Furthermore, there are few historical texts about Mongolia prior to the 1990s available in English. While the advantage of a case study is its ability to engage the complexity of detail, the Mongolian experience is perhaps too exceptional, given its unique place in history. These limitations notwithstanding, the case of Mongolia serves to re-emphasize the problems of existing welfare state typologies. It also highlights the problem of applying anti-poverty interventions that are not sustainable in the long-term, have an insufficient appreciation of the context, or do not involve local actors.

However, this case study suggests future directions for further research on global poverty, the welfare state, and social work practice. Most obviously, research on poverty and social policy responses in low-income countries, including the understudied East Asian and Central Asian republics, is needed. Future welfare state research needs to seriously consider the role of social capital and natural capital. Industry requires mineral extraction. Agriculture requires land and water and sunlight. As the world moves to measuring SDGs, rather than MDGs, sustaining natural capital will be a key element of measuring the performance of the welfare state. 


\section{Acknowledgments}

The author would like to thank Albert Acker, Sherylyn Briller, Sherrill Clark, Tara Eaton, Neil Gilbert, James Midgley and anonymous reviewers for helpful comments on versions of this paper. A version of this paper was presented at the conference of the

\section{References}

Aita, V. A., \& Mcllvain, H. (1999). An armchair adventure in case study research. In B. F. Crabtree \& W. L. Miller (Eds.), Doing qualitative research (2nd edn., pp. 256-268). Thousand Oaks, CA: Sage Publications, Inc.

Aspalter, C. (2006). The East Asian welfare model. International Journal of Social Welfare, 15(4), 290-301. doi:10.1111/j.1468-2397.2006.00413.x

Bahrampour, T. (2006, July 3). Mongolians meld old, new in making Arlington home. The Washington Post, p. A01. Retrieved from http://www.washingtonpost.com/wpdyn/content/article/2006/07/02/AR2006070200875.html

Bawden, C. R. (1968). The modern history of Mongolia. London: Weidenfeld and Nicolson.

Bawden, C. R. (1991). Mongolia and the Mongolians: An overview. In S. Akiner (Ed.), Mongolia today (pp. 9-31). London \& New York: Kegan Paul.

Benwell, A. F. (2006). Facing gender challenges in post-socialist Mongolia. In O. Bruun \& L. Narangoa (Eds.), Mongols from country to city: Floating boundaries, pastoralism and city life in the Mongol lands (pp. 110-139). Copenhagen: NIAS Press.

Blank, R. M. (2005). Poverty, policy, and place: How poverty and policies to alleviate poverty are shaped by local characteristics. International Regional Science Review, 28(4), 441-464. doi:10.1177/0160017605278999

Brundtland, G. H. (1987). Our common future: Report of the World Commission on Environment and Development. New York, N.Y: United Nations.

Bruun, O. \& Narangoa, L. (2006). A new moment in Mongol history: The rise of the cosmopolitan city. In Mongols from country to city: Floating boundaries, pastoralism and city life in the Mongol lands (pp. 1-20). Copenhagen: NIAS Press Copenhagen.

Butler, W. E. (1991). Law reform in Mongolia. In S. Akiner (Ed.), Mongolia today (pp. 79-93). London \& New York: Kegan Paul.

Campi, A. (2006). The rise of cities in nomadic Mongolia. In Mongols from country to city: Floating boundaries, pastoralism and city life in the Mongol lands (pp. 21-55). Copenhagen: NIAS Press Copenhagen.

Cardoso, F. H. (1972). Dependency and development in Latin America. New Left Review, 74, 83-9.

Central Intelligence Agency. (2013). The world factbook. Retrieved June 17, 2013, from https://www.cia.gov/library/publications/the-worldfactbook/geos/mg.html

Chambers, D. E. \& Wedel, K. R. (2004). Social policy and social programs: A method for the practical public policy analyst. Boston: Pearson/Allyn \& Bacon.

De Soto, H. (2003). The mystery of capital: Why capitalism triumphs in the West and fails everywhere else. New York, NY: Basic Civitas Books.

Esping-Andersen, G. (1990). The three worlds of welfare capitalism.

Esping-Andersen, G. (1992). The making of a social democratic welfare state. In K. Misgeld \& K. Molin (Eds.), J. Teeland (Trans.), Creating social democracy, A century of the social democratic labor party in Sweden (pp. 3566). University Park, PA: Pennsylvania State University Press.

Forsythe, M. (2010, February 15). Mongolian Harvard elites aim for wealth without "Dutch Disease." Bloomberg. Retrieved July 8, 2011, from http://www.bloomberg.com/apps/news?pid=newsarchive\&sid=aONmVLraqtO8

Friedman, T. (2006). The first law of petropolitics. Foreign Policy, (154), 28-
Association for Public Policy and Management entitled Asian Social Protection in Comparative Perspective, hosted in January 2009 at the Lee Kuan Yew School of Public Policy, National University of Singapore.

Ganbat, N. (2013, June 28). Mongolian leader re-elected on anti-graft agenda. $A B C$ News. Ulaanbaatar, Mongolia. Retrieved from http://abcnews.go.com/International/wireStory/mongolian-leader-elected-antigraft-agenda- 19515768

Giddens, A. (2000). The third way and its critics. Cambridge, UK \& Malden, MA: Polity Press. Blackwell Publishers.

Gilbert, N. (2009). The least generous welfare state? A case of blind empiricism. Journal of Comparative Policy Analysis: Research and Practice, 11(3), 355-367. doi:10.1080/13876980903221122

Griffin, K. B. (Ed.). (2003). Poverty reduction in Mongolia. Canberra: Asia Pacific Press.

Hall, A. L. \& Midgley, J. (2004). Chapter one: Social policy for development: Local, national and global dimensions. In Social policy for development (pp. 143). London \& Thousand Oaks, CA: SAGE.

Hayashi, R., Frost, C. J., Yamashita, E., Khuajin, U., \& Nyamsuren, B. (2009). Child welfare needs in Mongolia: A collaborative exploration among three universities. International Social Work, 52(1), 84-95. doi:10.1177/0020872808097753

Heissig, W. \& Samuel, G. (1980). The religions of Mongolia. London: Routledge \& K. Paul.

Holliday, I. (2000). Productivist welfare capitalism: Social policy in East Asia. Political Studies, 48(4), 706-723. doi:10.1111/1467-9248.00279

Hook, L. (2011, July 8). Boomtown Mongolia. Financial Times. Retrieved from http://www.ft.com/cms/s/2/7785732e-a84a-11e0-9f50-

00144feabdc0.html\#axzz1RXXzsfKe

Jones, J. F. \& Kumssa, A. (1997). Mongolia's transition to a market economy: Problems and prospects. Social Development Issues, 19(1), 50-62.

Kaplonski, C. (2004). Truth, history and politics in Mongolia: The memory of heroes. London ; New York: RoutledgeCurzon.

Kaser, M. (1991). Economic developments. In S. Akiner (Ed.), Mongolia today (pp. 94-122). London \& New York: Kegan Paul.

Khuldorj, B. (2012). Mongolia's sustainable development agenda: progresses, bottlenecks and vision for the future (p. 76). Ulaanbaatar, Mongolia: Ministry of Nature, Environment and Tourism. Retrieved from http://www.undp.mn/publications/rio_report_mongolia_eng.pdf

Kohn, M. (2013, June 26). Mongolia's Elbegdorj seeks re-election on antigraft drive. Bloomberg. Retrieved from http://www.bloomberg.com/news/201306-26/mongolia-s-elbegdorj-seeks-re-election-on-anti-corruption-drive.html

Lee, Y.-J. \& Ku, Y. (2007). East Asian welfare regimes: Testing the hypothesis of the developmental welfare state. Social Policy \& Administration, 41(2), 197-212. doi:10.1111/j.1467-9515.2007.00547.x

Li, W. D. H. (2013). East Asian welfare model refocus? A case study on economic support for the elderly living alone in Taiwan. International Journal of Social Welfare, 22(3), 260-268. doi:10.1111/j.1468-2397.2012.00899.x

Mearns, R. (2004). Sustaining livelihoods on Mongolia's pastoral commons: insights from a participatory poverty assessment. Development and Change, 35(1), 107-39. doi:10.1111/j.1467-7660.2004.00345.x

Midgley, J. (1986). Industrialization and welfare: The case of the four little tigers. Social Policy \& Administration, 20(3), 225-238. doi:10.1111/j.14679515.1986.tb00253.x 
Midgley, J. (1999). Growth, redistribution, and welfare: Toward social investment. Social Service Review, 73(1), 3-21. doi:10.1086/515795

Morgan, D. (1986). The Mongols. Oxford, UK \& New York, NY: B. Blackwell.

Myrdal, G. (1974). What is development? Journal of Economic Issues, 8(4), 729-736. Retrieved from http://www.jstor.org/stable/info/4224356

Namdaldagva, O.-E., Myagmarjav, S., \& Burnette, D. (2010). Professional social work education in Mongolia: Achievements, lessons learned and future directions. Social Work Education, 29(8), 882-895. doi:http://dx.doi.org/10.1080/02615479.2010.517017

National Development and Innovation Committee. (2009) Third national report: The millennium development goals implementation, Ulaanbaatar, Mongolia. Retrieved from http://www.undp.mn/publications/mdg3.pdf

National Statistics Office. (2009). Mongolia: Household socio-economic survey 2007-2008 (p. 48). Ulaanbaatar, Mongolia. Retrieved from http://go.worldbank.org/01PTGR3U30

Nixson, F., \& Walters, B. (1999). Administrative reform and economic development in Mongolia, 1990-1997: A critical perspective. Review of Policy Research, 16(2), 147-175. doi:10.1111/j.1541-1338.1999.tb00873.x

Nixson, F. \& Walters, B. (2006). Privatization, income distribution, and poverty: the Mongolian experience. World Development, 34(9), 1557-1579. doi:16/j.worlddev.2005.12.007

Officer, L. H., \& Williamson, S. H. (2011). MeasuringWorth. Retrieved from http://www.measuringworth.com

Okamoto, M. (2011). Safety net measures for Mongolian herders: Coping with risks in a transition economy. In J. Midgley \& M. Hosaka (Eds.), Grassroots social security in Asia: Mutual aid, microinsurance and social welfare (pp. 110122). Taylor \& Francis.

Prasad, U. (1995). Mongolia, making of nation state (Vol. 1st). Delhi: Bhavna Prakashan.

Rossabi, M. (2005). Modern Mongolia. Berkeley, CA: University of California Press.

Rostow, W. W. (1959). The stages of economic growth. The Economic History Review, 12(1), 1-16. Retrieved from http://www.jstor.org/stable/2591077

Sachs, J. (2005). Chapter one: A global family portrait. In The end of poverty: Economic possibilities for our time (pp. 5-25). New York: Penguin Press.

Safadi, N. S. \& Easton, S. D. (2014). The evolution of the social welfare system in Palestine: Perspectives of policymakers in the West Bank. International Journal of Social Welfare, 23(1), 52-60. doi:10.1111/ijsw.12017

Sanders, A. J. K. (1987). Mongolia: Politics, economics and society. London: Pinter.

Sneath, D. (2006). The rural and the urban in pastoral Mongolia. In O. Bruun \& L. Narangoa (Eds.), Mongols from country to city: Floating boundaries, pastoralism and city life in the Mongol lands (pp. 140-161). Copenhagen: NIAS Press Copenhagen.

Titmuss, R. M. (1965). The role of redistribution in social policy. Social Security Bulletin, 28, 14-20.

Townsend, P. (1974). Poverty and relative deprivation: Resources and style of living. In D. Wedderburn (Ed.), Poverty, inequality and class structure (pp. 15-42). London: Cambridge University Press.

United Nations. (2012, June 22). The future we want. Retrieved from http://www.uncsd2012.org/thefuturewewant.html

United Nations Development Program. (2011, October 19). Mongolia: UNDP chief calls for people-centred sustainable development as country faces mining boom. UNDP.

United Nations Development Program Mongolia. (2007). Employment and poverty in Mongolia. Ulaanbaatar, Mongolia: United Nations Development Program (UNDP). Retrieved from http://www.undp.mn/new/content/view/81

United Nations Development Program Mongolia. (2011). From vulnerability to sustainability: environment and human development. Ulaanbaatar, Mongolia: United Nations Development Program (UNDP).

United Nations Environment Program. (2012). Champions of the Earth United Nations Environment Program. Retrieved June 29, 2012, from http://www.unep.org/champions/laureates/2012/Elbegdorj.asp
Wallerstein, I. (1974). The rise and future demise of the world capitalist system: Concepts for comparative analysis. Comparative Studies in Society and History, 16(04), 387-415. doi:10.1017/S0010417500007520

Walters, B., Marshall, R., \& Nixson, F. (2012). Consistent and transparent? The problem of longitudinal poverty records. Development and Change, 43(4), 899-918. doi:10.1111/j.1467-7660.2012.01785.x

Wilensky, H. L. \& Lebeaux, C. N. (1958). Industrial society and social welfare: The impact of industrialization on the supply and organization of social welfare services in the United States. New York, NY: Russell Sage Foundation.

Woolcock, M. (1998). Social capital and economic development: Toward a theoretical synthesis and policy framework. Theory and Society, 27(2), 151208. doi:10.1023/A:1006884930135

World Bank. (2011) 'Mongolia - Data \& Statistics'. http://data.worldbank.org/country/mongolia (accessed 28 June 2011).

World Bank. (2012, February 28). Mongolia quarterly economic update. Retrieved from http://www.worldbank.org/en/news/feature/2012/02/28/mongolia-quarterlyeconomic-update-february-2012 